\title{
A Meta-Analysis of Randomized Clinical Trials Comparing Shorter (Less or Equal Than 6 Months) and Longer (More or Equal Than 12 Months) Dual Anti-Platelet Therapy Following Drug-Eluting Coronary Stents
}

\author{
Jian Yang ${ }^{1, *}$; Zhi-Xing Fan ${ }^{1}$; Chao-Jun Yang ${ }^{1}$; Hui-Bo Wang ${ }^{1}$ \\ ${ }^{1}$ Department of Cardiology, The First College of Clinical Medical Sciences, Institute of Cardiovascular Diseases, China Three Gorges University, Hubei Province, China \\ ${ }^{*}$ Corresponding Author: Jian Yang, Department of Cardiology, The First College of Clinical Medical Sciences, Institute of Cardiovascular Diseases, China Three Gorges University, P. O. \\ Box: 443000, Hubei Province, China. Tel: 15572788526, Fax:+717-6482302, E-mail: yichangyangjian@163.com
}

Received: January 11, 2015; Revised: March 28, 2015; Accepted: May 4, 2015

\begin{abstract}
Context:The optimal duration of dual anti-platelet therapy (DAPT) after the implantation of drug-eluting coronary stents (DES) is still the subject of ongoing debate. This meta-analysis wasperformed to investigate theoptimalduration between $\leq 6$ monthsand $\geq 12$ months for DAPT after implantation of DES.

Evidence Acquisition: This study was conducted at the department of cardiology, the first college of clinical medical sciences, institute of cardiovascular diseases of Three Gorges university during December 2014. Pub-med, Cochrane, Scopus and clinicaltrials.gov databases were searched for papers published until December 2014. Searches of the above databases included terms "dual anti-platelet therapy" and "myocardial infarction (MI)" and "drug-eluting stents (DES)". All the searched literatures were limited to Randomized Controlled Trials (RCTs). Quality assessments were evaluated with the Jadad quality scale. Data were extracted by two independent observers (FZ and YC). For all analyses, the 95\% confidence interval (CI) was calculated and heterogeneity of the studies was analyzed using I2 statistics.

Results: Five RCTs with 9979 participants satisfying the inclusion criteria were finally analyzed. Overall, there were 4993 patients with shorter duration of DAPT and 4986 patients with a longer treatment. Clopidogrel was the used P2Y12 receptor inhibitor in all five RCTs. On one hand compared to shorter duration ( $\leq 12$ months)DAPT, longer duration( $\geq 12$ months)did not reduce risk of mortality, cardiac death, cerebrovascular accidents, myocardial infarction and stent thrombosis (pooled OR 1.03, 95\% Confidence Interval (CI) $0.80-1.32, \mathrm{P}=0.85, \mathrm{I}^{2}$ $=0 \%$; pooled OR 0.91, 95\% CI 0.64-1.29, $\mathrm{P}=0.60, \mathrm{I}^{2}=0 \%$; pooled OR 0.84, 95\% CI 0.50 -1.42, $\mathrm{P}=0.51, \mathrm{I}^{2}=0 \%$; pooled OR 1.17, 95\% CI 0.87-1.58, $\mathrm{P}=$ $0.29, \mathrm{I}^{2}=0 \%$; pooled OR1.36, $95 \% \mathrm{CI} 0.81-2.29, \mathrm{P}=0.24, \mathrm{I}^{2}=0 \%$ ). On the other hand, longer duration ( $\geq 12$ months) could also increase the risk of thrombolysis in myocardial infarction (TIMI) major bleeding (pooled OR 0.50, 95\% CI 0.29- $0.85, \mathrm{P}=0.01, \mathrm{I}^{2}=0 \%$ ).

Conclusions: Regarding the efficacy outcomes of the patients after DES implantation, no differences were found between shorter ( $\leq 6$ months)and longer ( $\geq 12$ months) duration of DAPT. What is worse is that longer duration ( $\geq 12$ months) was associated with increased risk of bleeding complications.
\end{abstract}

Keywords:Drug-Eluting Stents; Dual Antiplatelet Therapy; Meta-Analysis

\section{Context}

Dual anti-platelet therapy (DAPT), which was defined as the use of a P2Y12 receptor inhibitor (clopidogrel (1), ticagrelor (2) or prasugrel (3)) and aspirin, is an important clinical treatment strategy for patients after implantation of drug eluting stents (DES) $(4,5)$. Current clinical guidelines recommend 12 months of DAPT in patients after implantation of DES, who are not at a high risk of bleeding, and suggest that early discontinuation of DAPT may result in stent thrombosis (4). However, considering the potential for TIMI major bleeding, the continuation of DAPT after DES implantation remains unclear (6-9). During the American Heart Association 2014 (AHA2014), many clinical trials (dual anti-platelet therapy (DAPT)) (10), intracoronary stenting and antithrombotic regimen: safety and efficacy of 6 months dual antiplatelet therapy after drug-eluting stenting
(ISAR-SAFE) (11) and is there a life for des after discontinuation of clopidogrel (ITALIC) (12)) about the optimal continuation time of DAPT after DES implantation were announced. However, the outcomes of these three clinical studies were different. Briefly, the outcomes from DAPT indicated that DAPT beyond one year after placement of DES could significantly reduce the risks of stent thrombosis, cerebrovascular events and major adverse cardiovascular, though with an increased risk of TIMI major bleeding. Conversely, patients assigned six months of DAPT had similar net clinical outcomes compared with patients assigned 12 months of DAPT after percutaneous coronary intervention (PCI) with a DES, according to new data from the ISAR-SAFE study. At the same time, the ITALIC trial showed that rates of bleeding and of thrombotic events were not significantly

Copyright ( 2015, Iranian Red Crescent Medical Journal. This is an open-access article distributed under the terms of the Creative Commons Attribution-NonCommercial 4.0 International License (http://creativecommons.org/licenses/by-nc/4.0/) which permits copy and redistribute the material just in noncommercial usages, provided the original work is properly cited. 
Yang J et al.

different for the six-month versus 24-month long DAPT after PCI with new generation DES in good aspirin responders. All in all, the optimal duration of DAPT after DES implantation remains uncertain until now. Here, a meta-analysis was performed to investigate the optimalduration, between $\leq 6$ months and $\geq 12$ months, for DAPT after implantation of DES.

\section{Evidence Acquisition}

A meta-analysis of available published researches about intervention of DAPT after DES implantation was performed. During December 2014, a literature search was conducted at the department of cardiology, the first college of clinical medical sciences, Institute of cardiovascular diseases, China, Three Gorges university. Articles, which had been published before December 2014 were preselected.

\subsection{Literature Search Strategy}

To identify all prospective randomized controlled trials (RCTs) of DAPT after DES implantation, we systematically searched the literature through the Pub-med, Scopus, Cochrane and clinicaltrials.gov databases. Searches of the above database included the following phrases, "dual anti-platelet therapy" and "Myocardial Infarction (MI)" and "drug-eluting stents (DES)." The search was filtered to show only English articles and was limited to clinical trials. The steps of the literature search process are summarized in Figure 1.

\subsection{Criterions of Inclusion and Exclusion}

The inclusion criteria were as follows: 1) randomized clinical trial, 2) patients with implantation of DES older than 18 years 3 ) DAPT $\leq 6$ months OR $\geq 12$ months, 4) DAPT used were aspirin and clopidogrel, 5) English language studies. We excluded trails that did not report any of the outcomes mentioned above and articles without the data available.

223 potentially relevant references identified and screened for relieved from electronic search

214 excluded based on title and abstract

9 references retrieved for full text review

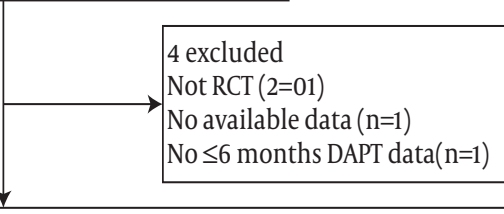

5 ECTs eligible randomized controlled trials included in the meta analysis

Figure 1. Flow Diagram of the Study Selection Process in the Meta-Analysis

\subsection{Data Collection Process}

The identification of titles and abstracts and extracting of data were independently screened by two reviewers (FZ and $\mathrm{YC}$ ). The corresponding author (YJ) was responsible for the potential of disagreement and discordance between the two reviewers. Quality assessments were evaluated with the Jadad quality scale (a numerical score between zero and seven, with zero being the weakest and seven being the strongest), including the following: 1) double blinding, 2) allocation concealment, 3) random sequence generation and 4) description of withdrawals and drop-outs.

\subsection{Statistical Analysis}

All statistical analyses were performed using the RevMan 5.0 software, provided by the Cochrane Collaboration. The effect measure of odds ratio (OR) with 95\% Confidence Interval (CI) and the statistical method of random effects were used. Heterogeneity was assessed using $\mathrm{I}^{2}$ statistics and the statistical significance was set at 0.05.

\section{Results}

\subsection{Included Clinical Trials}

There were 223 relevant reports identified by the search; nine full text articles were retrieved for detailed evaluation. In total, five RCTs enrolling 9,979 participants (4,993 patients were with shorter duration of DAPT and 4,986 patients with a longer treatment) satisfying the inclusion criteria were finally analyzed. Figure 1 shows the flow diagram of the study selection process in the meta-analysis. According to the Jadad quality scale, all included trials were of general quality (the score was five), as indicated by Table 1. All five RCTs were published between 2012 and 2014 and all the five RCTs were open-label yet not double blind, which may bias the results.

\subsection{Characteristics of the Included Clinical Trials}

The baseline characteristics of patients in both $\leq 6$ months and $\geq 12$ months groups were similar (characteristics of the clinical trials are shown in Table 2). Females were under-represented compared to males in all trials (about 30\%). Participants in all five RCTs had a mean age of 63 years and there were about $49 \%$ acute coronary syndromes (ACS) patients in this meta-analysis. The mean duration of the shorter duration group was 4.8 months while for the longer duration group this was 17 months.

\subsection{The Results of Data Analysis}

All the five RCTs had a good homogeneity, thus this meta-analysis used a fixed effects model. All causes of death, MI, cardiac death, cerebrovascular accident, stent thrombosis and major bleeding were assessed 
Table 1. Summary of Quality Evaluation by the Jadad Scale for Clinical Trials of Dual Anti-Platelet Therapy After Drug Eluting Stents Implantation

\begin{tabular}{|c|c|c|c|c|c|}
\hline Trials & $\begin{array}{l}\text { Random Sequence } \\
\text { Generation }\end{array}$ & $\begin{array}{l}\text { Allocation } \\
\text { Concealment }\end{array}$ & Double Blinding & $\begin{array}{c}\text { Description of } \\
\text { Withdrawals and Drop-Out }\end{array}$ & Score \\
\hline Excellent (13) 2012 & 2 & 1 & 1 & 1 & 5 \\
\hline Prodigy (14) 2012 & 2 & 1 & 1 & 1 & 5 \\
\hline Reset (15) 2012 & 2 & 1 & 1 & 1 & 5 \\
\hline Optimize (16) 2013 & 2 & 1 & 1 & 1 & 5 \\
\hline Italic (12) 2014 & 2 & 1 & 1 & 1 & 5 \\
\hline
\end{tabular}

Table 2. Characteristics of the Included Clinical Trials a,b

\begin{tabular}{|c|c|c|c|c|c|c|c|c|c|c|}
\hline \multirow{2}{*}{$\begin{array}{l}\text { Clinical Trials } \\
\text { Group }\end{array}$} & \multicolumn{2}{|c|}{ Excellent (13) 2012} & \multicolumn{2}{|c|}{ Prodigy (14) 2012} & \multicolumn{2}{|c|}{ Reset (15) 2012} & \multicolumn{2}{|c|}{ Optimize (16) 2013} & \multicolumn{2}{|c|}{ Italic (12) 2014} \\
\hline & $\begin{array}{l}\text { Shorter } \\
(n=722)\end{array}$ & $\begin{array}{l}\text { Longer }(\mathrm{n} \\
\quad=721)\end{array}$ & $\begin{array}{l}\text { Shorter } \\
(\mathrm{n}=737)\end{array}$ & $\begin{array}{l}\text { Longer } \\
(n=741)\end{array}$ & $\begin{array}{l}\text { Shorter } \\
(\mathrm{n}=1059)\end{array}$ & $\begin{array}{c}\text { Longer } \\
(\mathrm{n}=1058)\end{array}$ & $\begin{array}{l}\text { Shorter } \\
(n=1563)\end{array}$ & $\begin{array}{l}\text { Longer } \\
(\mathrm{n}=1556)\end{array}$ & $\begin{array}{l}\text { Shorter } \\
(n=910)\end{array}$ & $\begin{array}{l}\text { Longer } \\
(\mathrm{n}=912)\end{array}$ \\
\hline Identifier NO. & \multicolumn{2}{|c|}{ NCT00698607 } & \multicolumn{2}{|c|}{ NCT00611286 } & \multicolumn{2}{|c|}{ NCT01145079 } & \multicolumn{2}{|c|}{ NCT01113372 } & \multicolumn{2}{|c|}{ NCT 01476020} \\
\hline Female $^{b}$ & 34.9 & 36.1 & 24.0 & 22.6 & 35.6 & 37.1 & 36.5 & 36.9 & 19.2 & 20.8 \\
\hline Age, $y$ & 63.0 & 62.4 & 67.9 & 67.8 & 62.4 & 62.4 & 61.3 & 61.9 & 61.7 & 61.5 \\
\hline $\operatorname{ACS}^{b}$ & 51.1 & 52.0 & 73.5 & 73.3 & 55.5 & 53.7 & 31.6 & 32.3 & 43.4 & 43.5 \\
\hline Sent type & \multicolumn{2}{|c|}{$\begin{array}{l}\text { Sirolimus Everoli- } \\
\text { mus }\end{array}$} & \multicolumn{2}{|c|}{$\begin{array}{l}\text { Paclitaxel Everoli- } \\
\text { mus Zotarolimus }\end{array}$} & \multicolumn{2}{|c|}{$\begin{array}{l}\text { Sirolimus Everolimus } \\
\text { Zotarolimus }\end{array}$} & \multicolumn{2}{|c|}{ Zotarolimus } & \multicolumn{2}{|c|}{ Xience V } \\
\hline $\begin{array}{l}\text { Duration of } \\
\text { DAPT, months }\end{array}$ & 6 & 12 & 6 & 24 & 3 & 12 & 3 & 12 & 6 & 24 \\
\hline Intervention & \multicolumn{2}{|c|}{$\begin{array}{l}12 \text { month aspirin or } \\
\text { clopidogrel versus } 3 \\
\text { month aspirin and } \\
\text { clopidogrel }\end{array}$} & \multicolumn{2}{|c|}{$\begin{array}{l}24 \text { month aspirin or } \\
\text { clopidogrel versus } 6 \\
\text { month aspirin and } \\
\text { clopidogrel }\end{array}$} & \multicolumn{2}{|c|}{$\begin{array}{c}12 \text { month aspirin or } \\
\text { clopidogrel versus } 3 \\
\text { month aspirin and } \\
\text { clopidogrel }\end{array}$} & \multicolumn{2}{|c|}{$\begin{array}{c}12 \text { month aspirin or } \\
\text { clopidogrel versus } 3 \\
\text { month aspirin and } \\
\text { clopidogrel }\end{array}$} & \multicolumn{2}{|c|}{$\begin{array}{l}24 \text { month aspirin } \\
\text { or clopidogrel ver- } \\
\text { sus } 6 \text { month aspirin } \\
\text { and clopidogrel }\end{array}$} \\
\hline $\begin{array}{l}\text { Primary end } \\
\text { point }\end{array}$ & \multicolumn{2}{|c|}{$\begin{array}{l}\text { Composite of all } \\
\text { cause death, MI, } \\
\text { stroke, or major } \\
\text { bleeding }\end{array}$} & \multicolumn{2}{|c|}{$\begin{array}{l}\text { Composite of all } \\
\text { cause death, MI, } \\
\text { stroke, or major } \\
\quad \text { bleeding }\end{array}$} & \multicolumn{2}{|c|}{$\begin{array}{l}\text { Composite of all } \\
\text { cause death, MI, } \\
\text { stroke, or major } \\
\quad \text { bleeding }\end{array}$} & \multicolumn{2}{|c|}{$\begin{array}{l}\text { Composite of all } \\
\text { cause death, MI, } \\
\text { stroke, or major } \\
\text { bleeding }\end{array}$} & \multicolumn{2}{|c|}{$\begin{array}{l}\text { Composite of all } \\
\text { cause death, MI, } \\
\text { stroke, or major } \\
\text { bleeding }\end{array}$} \\
\hline
\end{tabular}

\footnotetext{
a Abbreviations: ACS, acute coronary syndromes; DAPT, Dual Anti-Platelet Therapy; MI, myocardial infarction.
}

$\mathrm{b}$ Values are presented as \%.

in this meta-analysis. Longer duration of therapy ( $\geq 12$ months) did not reduce the risk of mortality, including, all causes of death, cardiac death, cerebrovascular accidents, myocardial infarction and stent thrombosis (pooled OR 1.03, 95\% CI $0.80-1.32, \mathrm{P}=0.85, \mathrm{I}^{2}=0 \%$, Figure 2 A; pooled OR 0.91, 95\% CI $0.64-1.29, \mathrm{P}=0.60, \mathrm{I}^{2}=0 \%$, Figure $2 \mathrm{~B}$; pooled OR 0.84, 95\% CI $0.50-1.42, \mathrm{P}=0.51, \mathrm{I}^{2}=$ $0 \%$, Figure 2 C; pooled OR 1.17, 95\% CI $0.87-1.58, \mathrm{P}=0.29$, $\mathrm{I}^{2}=0 \%$, Figure 2 D; pooled OR 1.36, 95\% CI $0.81-2.29, \mathrm{P}=$ $0.24, \mathrm{I}^{2}=0 \%$, Figure $2 \mathrm{E}$ ). Longer duration ( $\geq 12$ months) increased the risk of TIMI major bleeding (pooled OR $0.50,95 \%$ CI $0.29-0.85, \mathrm{P}=0.01, \mathrm{I}^{2}=0 \%$; Figure 3 ). The total events of primary end points of DAPT after DES implantation are summarized in Table 3.

\subsection{Evaluation for Publication Bias}

Considering all the five RCTs, the funnel plot of all causes of mortality was symmetrical (Figure 4), which indicates that publication bias is low. 
Yang J et al.

Figure 2. Effect of Long and Short Duration of Therapy on the Risk of Death Caused by Cardiac Arrest, Cerebrovascular Accidents, Myocardial Infarction, Stent Thrombosis and Other Causes of Death

\begin{tabular}{|c|c|c|c|c|c|c|c|}
\hline \multirow{2}{*}{ A_study or Subgroup } & \multicolumn{2}{|c|}{ shorter duration } & \multicolumn{2}{|c|}{ Jonaer dure } & \multicolumn{3}{|c|}{ Odds Ratlo } \\
\hline & & Total & Events & Total & feight $m$. & U-H. Fixed, 95: C & Year \\
\hline RESET 2012 & 5 & 1059 & 7 & 1058 & $5.9 \%$ & $0.71[0.23,2.25]$ & 2012 \\
\hline PRODIGY 2012 & 47 & 737 & 49 & 741 & $39.0 \%$ & $0.96[0.64,1.46]$ & 2012 \\
\hline EXCELLENT 2012 & 15 & 722 & 7 & 721 & $5.9 \%$ & $2.16[0.88,5.34]$ & 2012 \\
\hline OPTIMIZE 2013 & 43 & 1563 & 45 & 1556 & $37.4 \%$ & $0.95[0.62,1.45]$ & 2013 \\
\hline ITALIC 2014 & 15 & 912 & 14 & 910 & $11.8 \%$ & $1.07[0.51,2.23]$ & 2014 \\
\hline Total (95\% CD) & & 4993 & & 4986 & $100.0 \%$ & $1.03[0.80,1.32]$ & \\
\hline \multicolumn{8}{|c|}{$\begin{array}{l}\text { Total events } \\
\text { Heterogeneity: Chi }{ }^{2}=3.24, \quad 125 \\
\text { Test for overall effect: } Z=0(P=0.20(P=0.85)\end{array}$} \\
\hline & \multicolumn{2}{|c|}{ shorter duration } & \multicolumn{2}{|c|}{ longer duration } & \multicolumn{3}{|c|}{ Odds Ratlo } \\
\hline Study or Subgroup & Events & Total & Events & Total & Weight $M$ & $\mathrm{M}-\mathrm{H}$, Fixed, $95 \% \mathrm{Cl}$ & Year \\
\hline EXCELLENT 2012 & 2 & 722 & 3 & 721 & 4.48 & $0.66[0.11,3.99]$ & 2012 \\
\hline RESET 2012 & 2 & 1059 & 4 & 1058 & $5.9 \%$ & $0.50[0.09,2.73]$ & 2012 \\
\hline PRODIGY 20 & 25 & 737 & 27 & 741 & $38.6 \%$ & $0.93[0.53,1.62]$ & 2012 \\
\hline OPTIMIZ & 29 & 1563 & 32 & 1556 & $46.7 \%$ & 0.90 & 2013 \\
\hline ITALIC 2014 & 5 & 912 & 3 & 910 & $4.4 \%$ & $1.67[0.40,6.99]$ & 2014 \\
\hline otal (95\% CD) & & 4993 & & & $\mathbf{x}$ & $.91[0.64,1.29]$ & \\
\hline
\end{tabular}

Total events
Heterogeneity: $C h i^{2}=1.29, \mathrm{df}^{6}=4(\mathrm{P}=0.86) ; \mathrm{l}^{2}=0 \%$

Test for overall effect: $Z=0.53(P=0.60)$

$\begin{array}{ccccc}\text { Shorter duration longer duration } & \text { Odds Ratlo } \\ \text { C Study or Subgroup } & \text { Events Total Events Total Weight M-H, Fixed, } 95 \% \mathrm{Cl} \text { Year }\end{array}$ \begin{tabular}{lrrrrrrr} 
Study or Subgroup & Events & Total & Events & Total & Weight M-H, Fixed, 95\% Cl & Year \\
\hline EXCELLENT 2012 & 3 & 722 & 5 & 721 & $16.2 \%$ & $0.60[0.14,2.51]$ & 2012
\end{tabular} \begin{tabular}{lllrrrr} 
PRODIGY 2012 & 3 & 722 & 5 & 721 & $16.2 \%$ & $0.60[0.14,2.51]$ \\
\hline & 7 & 737 & 13 & 747 & $41.6 \%$ & $0.54[0.21,1.36] 2012$
\end{tabular} $\begin{array}{lllllll}\text { RESET } 2012 & 6 & 1059 & 6 & 1058 & 19.4 \% & 1.00[0.32,3.11] \\ 2012\end{array}$ \begin{tabular}{lllllll} 
OPTIMIZE 2013 & 5 & 1563 & 5 & 1556 & $16.3 \%$ & $1.00[0.29,3.45]$ \\
\hline & 5 & 912 & & 913
\end{tabular} $\begin{array}{lrrrrrr}\text { ITALIC } 2014 & 5 & 912 & 2 & 910 & 6.5 \% & 2.50[0.48,12.93] 2014\end{array}$

$\begin{array}{llllll}\text { Total }(95 \% \mathrm{Cl}) & 4993 & 4992 & 100.0 \% & 0.84 & {[0.50,1.42]}\end{array}$

$\begin{array}{ll}\text { Total events } & 26 \\ \text { Heterogeneity: } \mathrm{Ch}^{2}=2.94, \mathrm{df}=4(\mathrm{P}=0.57) ; \mathrm{I}^{2}=0 \%\end{array}$

Heterogeneity: $\mathrm{Ch}^{2}=2.94, \mathrm{df}=4(\mathrm{P}=0.57)$
Test for overall effect: $\mathrm{Z}=0.65(\mathrm{P}=0.51)$

$4992100.0860 .84[0.50,1.42]$

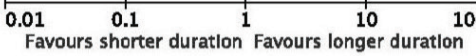

M-H. Fixed, $95 \% \mathrm{CI}$

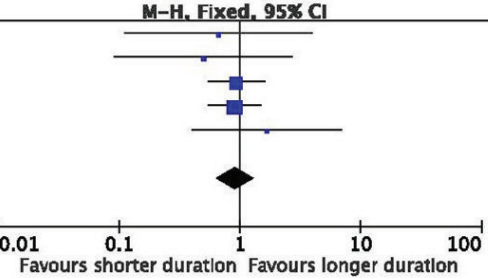

Odds Ratio

M-H. Fixed, $95 \% \mathrm{CI}$

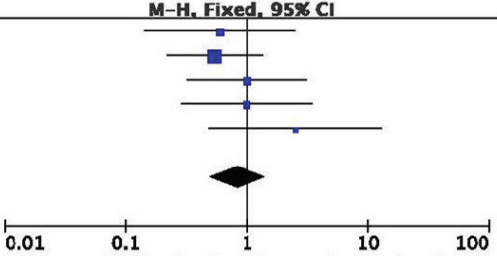

Favours shorter duration Favours longer duration

D shorter duration longer duration Odds Ratio Events Total Events Total Weight M-H, Fixed.95\% Cl Year PRODIGY 2012 EXCELLENT 2012 RESET 2012 OPTIMIZE 2013 ITALIC 2014

Total (95\% Cl)

Total events

$26 \quad 737$
737
722
1059

1059
1563
912

$\begin{array}{rrr}25 & 741 & 30.2 \% \\ 7 & 721 & 8.6 \% \\ 4 & 1058 & 5.0 \% \\ 42 & 1556 & 51.2 \%\end{array}$

$1.05[0.60,1.83] 2012$ $1.87[0.74,4.72] 201$ $0.50[0.09,2.73] 2012$ $1.17[0.77,1.77] 201$ $1.50[0.42,5.33] 2014$

4993

$96 \quad 82$

Test for overall effect: $Z=1.06(P=0.29)$

$4986100.0 \% 1.17[0.87,1.58]$

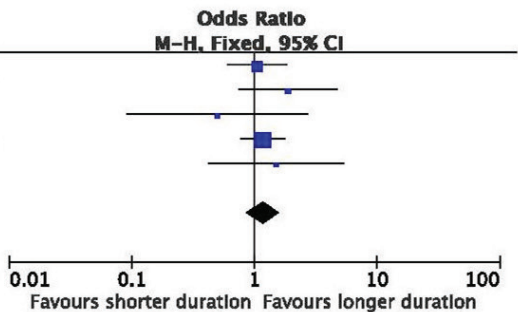

E shorter duration longer duration Odds Ratio

Events Total Events Total PRODIGY 2012 RESET 2012 EXCELLENT 2012
OPTIMIZE 2013 OPTIMIZE 2013
ITALIC 2014

$10 \quad 737$
$\begin{array}{rr}10 & 737 \\ 2 & 1059 \\ 6 & 722\end{array}$

$\begin{array}{rrr}7458 & 12.1 \%\end{array}$

$721 \quad 4.0 \%$

$1556 \quad 48.1 \%$

$1.26[0.49,3.21] 2012$ $0.67[0.11,3.99] 2012$ $6.03[0.72,50.24] 2012$ $6.03[0.72,50.24]$
$1.08[0.49,2.37] 2013$

\section{Total (95\% Cl)}

912

4993

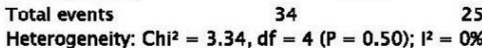

Test for overall effect: $Z=1.17(P=0.24)$

$4986100.0 \% 1.36[0.81,2.29]$

25

Pooled OR1.03, 95\% CI 0.80-1.32, P= 0.85, $\mathrm{I}^{2}=0 \%, \mathrm{~A}$; pooled OR 0.91, 95\% CI 0.64-1.29, P=0.60, $\mathrm{I}^{2}=0 \%, \mathrm{~B}$; pooled OR 0.84, $95 \% \mathrm{CI} 0.50-1.42, \mathrm{P}=0.51, \mathrm{I}^{2}=0 \%$, C; pooled OR 1.17, 95\% CI $0.87-1.58, \mathrm{P}=0.29, \mathrm{I}^{2}=0 \%$, D; pooled OR $1.36,95 \% \mathrm{CI} 0.81-2.29, \mathrm{P}=0.24, \mathrm{I}^{2}=0 \%, \mathrm{E}$.

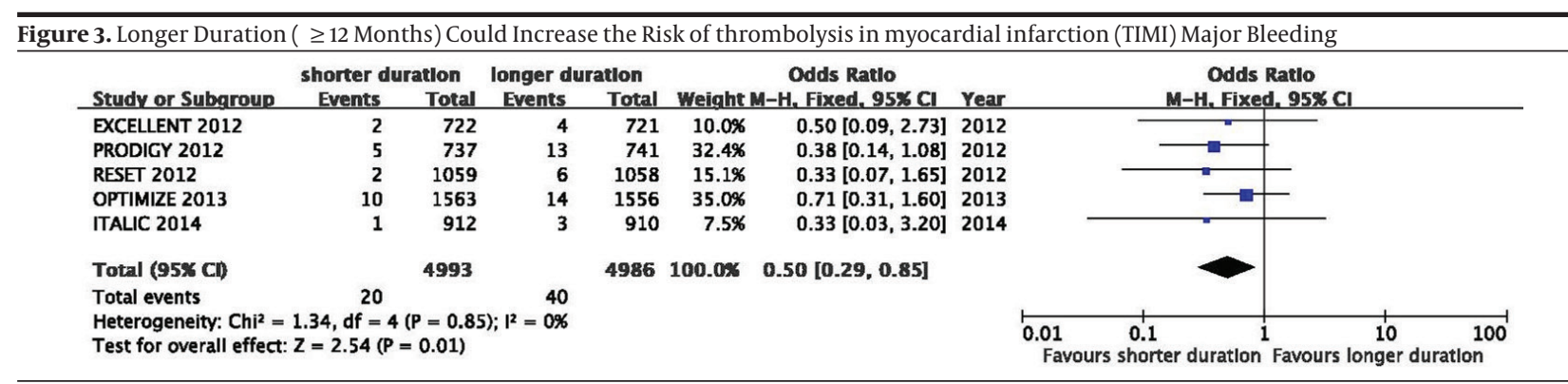

Pooled OR 0.50, 95\% CI 0.29- 0.85, $\mathrm{P}=0.01, \mathrm{I}^{2}=0 \%$ 
Yang J et al.

Table 3. Summary of Primary End Points of Clinical Trials of Dual Anti-Platelet Therapy After Drug Eluting Stents Implantation

\begin{tabular}{lcccc}
\hline Primary end Points & $\begin{array}{c}\text { Shorter, } \leq \mathbf{6} \mathbf{~ m o},(\mathbf{n}= \\
\mathbf{4 9 9 3})\end{array}$ & $\begin{array}{c}\text { Longer, } \geq \mathbf{1 2} \mathbf{~ m o},(\mathbf{n}= \\
\mathbf{4 9 8 6})\end{array}$ & OR & PValue \\
\hline All causes of mortality & 125 & 122 & $1.03(0.80,1.32)$ & 0.85 \\
Cardiac death & 63 & 69 & $0.91(0.64,1.29)$ & 0.60 \\
Cerebrovascular & 26 & 31 & $0.84(0.50,1.42)$ & 0.51 \\
MI & 96 & 82 & $1.17(0.87,1.58)$ & 0.29 \\
Stent thrombosis & 34 & 25 & $1.36(0.81,2.29)$ & 0.24 \\
TIMI major bleeding & 20 & 40 & $0.50(0.29,0.85)$ & 0.01 \\
\hline
\end{tabular}

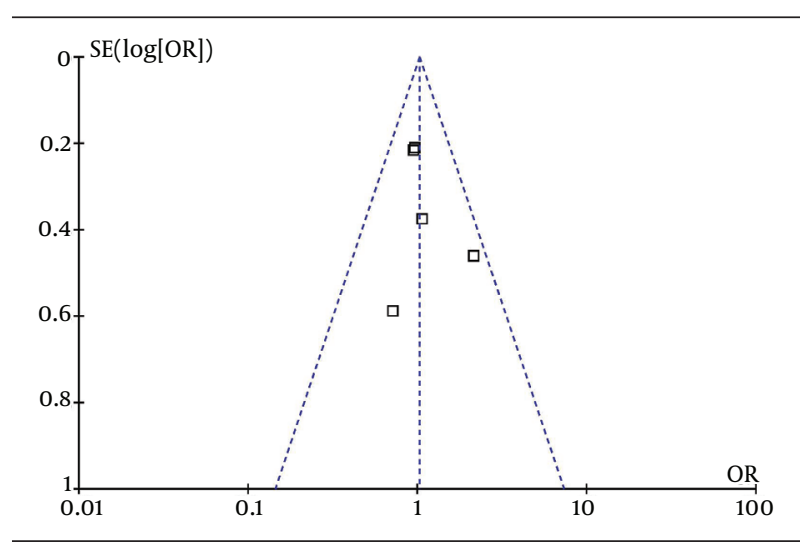

Figure 4. The Funnel Plot for All Causes of Mortality

\section{Conclusions}

Current clinical guidelines recommend 12 months of DAPT following implantation of DES $(4,9,17,18)$. However, the optimal duration of DAPT after implantation of DES remains undetermined. Recently, some RCTs have compared the different outcomes between shorter and longer duration of DAPT after DES implantation (10-12). However, the outcomes are still the subject of ongoing debate (19).

During the AHA2014, many clinical trials (DAPT, ISARSAFE and ITALIC) about the optimal duration of DAPT after DES implantation were announced. However, the outcomes from these three clinical studies were different. Briefly, the outcomes from DAPT indicated that DAPT beyond one year after placement of a DES significantly reduced the risks of cerebrovascular events, stent thrombosis and major adverse cardiovascular, though with an increased risk of TIMI major bleeding. Conversely, patients assigned to six months of DAPT had similar net clinical outcomes compared with patients assigned to 12 months of DAPT after PCI with a DES, according to new data from the ISAR-SAFE study. At the same time, the ITALIC trial showed that rates of bleeding and of thrombotic events were not significantly different for the 6-versus 24 -month DAPT program after PCI with new generation DES in good aspirin responders.

Here, a meta-analysis was performed to investigate the different outcomes between $\leq 6$ months and $\geq 12$ months DAPT after DES. Our findings were in agreement with previous publications (7-9). However, it also had some differences with previous reports. The biggest difference was that we included the latest clinical study (ITALIC). Similarly, the latest published meta-analysis, (6) carried out by Elmariah et al. (6) identified 14 eligible trials (but without ITALIC) that randomly assigned 69644 participants to different durations of DAPT. The outcomes indicated that compared with aspirin alone or short duration of DAPT, continued treatment was not associated with a difference in all causes of mortality, cardiovascular and non-cardiovascular mortality. Thus, compared to the meta-analysis of Elmariah et al. (6) our meta-analysis only analyzed the shorter ( $\leq 6$ months) and longer ( $\geq 12$ months) duration of DAPT without comparing aspirin alone. However, the outcomes of our meta-analysis were also in agreement with this meta-analysis. In other words, the findings of our meta-analysis suggested that to stabilize coronary atherosclerotic heart disease (CAD) patients, the duration of $\leq$ 6 months and $\geq 12$ months may be equally effective yet the longer duration was associated with increased risk of bleeding.

Of course, this meta-analysis also had some limitations; there was no patient level data and the five RCIs were not double blinded. Besides, different stent types were used in these five different studies (Table 2), which may also affect the outcome. Third, the only used P2Y12 receptor inhibitor in this meta-analysis was clopidogrel. The other inhibitors, ticagrelor and prasugrel, were not included in the analysis. Last but not least, the five studies had a low event rate, and ITALIC was prematurely terminated due to problems with recruitment, which would influence the quality of the clinical trials.

The optimal duration for DAPT after the implantation of DES is still undetermined. In clinical practice, the treatment plan of DAPT on different patients should be based on the individual's specific circumstances. For example, patients with a history or other risk factors for bleeding may be suitable for shortened period of DAPT. While, patients with a higher risk of thrombotic events (for example, with a variety of ischemic disease or multiple risk factors) should be on extended treatment. This meta-analysis was only an investigation in this area and the results may be more appropriately ap- 
plied to stable CAD patients.

\section{Acknowledgements}

The authors wish to offer their special thanks to Dr. Jun Yang, Dean of the Department of Cardiology, for his guidance and financial supports.

\section{Authors' Contributions}

The identification of titles and abstracts and extracting of data were independently screened by Zhi-Xing Fan and Chao-Jun Yang. Hui-Bo Wang was responsible for the potential of disagreement and discordance between ZhiXing Fan and Chao-Jun Yang. The corresponding author, Jian Yang, contributed to the development of the protocol and prepared the manuscript.

\section{Funding/Support}

This work was supported by the National Natural Science Foundation of China (Grant No. 81200088 and 81470387), the Natural Science Foundation of Yichang city (Grant No. A12301-01) and the Hubei Province Outstanding Medical Academic Leader Program of China.

\section{References}

1. Steinhubl SR, Berger PB, Mann J3, Fry ET, DeLago A, Wilmer C, et al. Early and sustained dual oral antiplatelet therapy following percutaneous coronary intervention: a randomized controlled trial. JAMA. 2002;288(19):2411-20.

2. Wallentin L, Becker RC, Budaj A, Cannon CP, Emanuelsson H, Held $\mathrm{C}$, et al. Ticagrelor versus clopidogrel in patients with acute coronary syndromes. N Engl J Med. 2009;361(11):1045-57.

3. Wiviott SD, Braunwald E, McCabe CH, Montalescot G, Ruzyllo W, Gottlieb S, et al. Prasugrel versus clopidogrel in patients with acute coronary syndromes. N Engl J Med. 2007;357(20):2001-15.

4. Levine GN, Bates ER, Blankenship JC, Bailey SR, Bittl JA, Cercek B, et al. 2011 ACCF/AHA/SCAI Guideline for Percutaneous Coronary Intervention: a report of the American College of Cardiology Foundation/American Heart Association Task Force on Practice Guidelines and the Society for Cardiovascular Angiography and Interventions. Circulation. 2011;124(23):e574-651.

5. Authors/Task Force M, Windecker S, Kolh P, Alfonso F, Collet JP, Cremer J, et al. 2014 ESC/EACTS Guidelines on myocardial revascularization: The Task Force on Myocardial Revascularization of the European Society of Cardiology (ESC) and the European Association for Cardio-Thoracic Surgery (EACTS)Developed with the special contribution of the European Association of Percutaneous Cardiovascular Interventions (EAPCI). Eur Heart J. 2014;35(37):2541-619.

6. Elmariah S, Mauri L, Doros G, Galper BZ, O'Neill KE, Steg PG, et al.
Extended duration dual antiplatelet therapy and mortality: a systematic review and meta-analysis. Lancet. 2015;385(9970):792-8.

7. Valgimigli M, Park SJ, Kim HS, Park KW, Park DW, Tricoci P, et al. Benefits and risks of long-term duration of dual antiplatelet therapy after drug-eluting stenting: a meta-analysis of randomized trials. Int J Cardiol. 2013;168(3):2579-87.

8. Pandit A, Giri S, Hakim FA, Fortuin FD. Shorter $(<\mid=6$ months $)$ versus longer $(>\mid=12$ months) duration dual antiplatelet therapy after drug eluting stents: a meta-analysis of randomized clinical trials. Catheter Cardiovasc Interv. 2015;85(1):34-40.

9. El-Hayek G, Messerli F, Bangalore S, Hong MK, Herzog E, Benjo A, et al. Meta-analysis of randomized clinical trials comparing short-term versus long-term dual antiplatelet therapy following drug-eluting stents. Am J Cardiol. 2014;114(2):236-42.

10. Mauri L, Kereiakes DJ, Yeh RW, Driscoll-Shempp P, Cutlip DE, Steg PG, et al. Twelve or 30 months of dual antiplatelet therapy after drug-eluting stents. N Engl J Med. 2014;371(23):2155-66.

11. Schulz-SS, Byrne RA, Ten Berg JM, Neumann FJ, Han Y, Adriaenssens T. ISAR-SAFE: a randomized, double-blind, placebo-controlled trial of 6 vs. 12 months of clopidogrel therapy after drugeluting stenting. Eur Heart J. 2015;36(20):1252-63.

12. Gilard M, Barragan P, Noryani AA, Noor HA, Majwal T, Hovasse T, et al. 6- versus 24-month dual antiplatelet therapy after implantation of drug-eluting stents in patients nonresistant to aspirin: the randomized, multicenter ITALIC trial. J Am Coll Cardiol. 2015;65(8):777-86.

13. Gwon HC, Hahn JY, Park KW, Song YB, Chae IH, Lim DS, et al. Sixmonth versus 12-month dual antiplatelet therapy after implantation of drug-eluting stents: the Efficacy of Xience/Promus Versus Cypher to Reduce Late Loss After Stenting (EXCELLENT) randomized, multicenter study. Circulation. 2012;125(3):505-13.

14. Valgimigli M, Borghesi M, Tebaldi M, Vranckx P, Parrinello G, Ferrari R, et al. Should duration of dual antiplatelet therapy depend on the type and/or potency of implanted stent? A pre-specified analysis from the PROlonging Dual antiplatelet treatment after Grading stent-induced Intimal hyperplasia studY(PRODIGY). Eur Heart J. 2013;34(12):909-19.

15. Kim BK, Hong MK, Shin DH, Nam CM, Kim JS, Ko YG, et al. A new strategy for discontinuation of dual antiplatelet therapy: the RESET Trial (REal Safety and Efficacy of 3-month dual antiplatelet Therapy following Endeavor zotarolimus-eluting stent implantation). J Am Coll Cardiol. 2012;60(15):1340-8.

16. Feres F, Costa RA, Abizaid A, Leon MB, Marin-Neto JA, Botelho RV et al. Three vs twelve months of dual antiplatelet therapy after zotarolimus-eluting stents: the OPTIMIZE randomized trial JAMA. 2013;310(23):2510-22.

17. Lee CW. Dual antiplatelet therapy for coronary artery disease. Circ J. 2015;79(2):255-62.

18. Hamidian S, Omidi A, Mousavinasab SM, Naziri G. Comparison of the Effect of Mindfulness-based Cognitive Therapy Accompanied by Pharmacotherapy With Pharmacotherapy Alone in Treating Dysthymic Patients. Iran Red Crescent Med J. 2013;15(3):239-44.

19. Kereiakes DJ, Yeh RW, Massaro JM, Driscoll-Shempp P, Cutlip DE, Steg PG, et al. Antiplatelet therapy duration following bare metal or drug-eluting coronary stents: the dual antiplatelet therapy randomized clinical trial.JAMA. 2015;313(11):1113-21. 